\title{
Assessing the effect of lay-rescuer gender on chest compression quality when using an automated external defibrillator in a simulated sudden cardiac arrest
}

Torney, H., Harvey, A., McAlister, O., Bond, RR., Finlay, D., Magee, J., McEneaney, D., \& Adgey, J. (2019). Assessing the effect of lay-rescuer gender on chest compression quality when using an automated external defibrillator in a simulated sudden cardiac arrest. Abstract from ESC Congress, Paris, France. https://doi.org/10.1016/j.resuscitation.2019.06.122

Link to publication record in Ulster University Research Portal

Publication Status:

Published (in print/issue): 30/09/2019

DOI:

10.1016/j.resuscitation.2019.06.122

\section{Document Version}

Author Accepted version

\section{General rights}

Copyright for the publications made accessible via Ulster University's Research Portal is retained by the author(s) and / or other copyright owners and it is a condition of accessing these publications that users recognise and abide by the legal requirements associated with these rights.

\section{Take down policy}

The Research Portal is Ulster University's institutional repository that provides access to Ulster's research outputs. Every effort has been made to ensure that content in the Research Portal does not infringe any person's rights, or applicable UK laws. If you discover content in the Research Portal that you believe breaches copyright or violates any law, please contact pure-support@ulster.ac.uk. 


\section{Assessing the Effect of Lay-Rescuer Gender on Chest Compression Quality in a Simulated Sudden Cardiac Arrest}

\section{Hannah Torney, Dr Adam Harvey, Olibhear McAlister, Dr Raymond Bond, Prof Dewar Finlay, Dr Justin Magee, Dr David McEneaney, Prof Jennifer Adgey}

Introduction:

Survival from sudden cardiac arrest (SCA) relies on prompt defibrillation and effective cardiopulmonary resuscitation (CPR). The effect of SCA patient gender has been assessed, but there has been little research into the effect of rescuer gender. An update to the resuscitation guidelines recommends lay-rescuers perform chest compression (CC) only CPR. This study was conducted to assess quality of CCs performed by male and female layrescuers.

\section{Methods:}

Lay-rescuers ( $n=141,48.2 \%$ male) were randomly recruited in a shopping mall to use a HeartSine SAM 450P public access defibrillator and perform CC on a manikin in a simulated SCA. Audio-visual CPR rate feedback was provided to 68 participants (48.2\%, 50\% male). CC rate, depth and fraction performed by male and female participants was assessed. Wilcoxon and t-tests were used where appropriate.

Results:

As shown in Figure 1, there was no difference in $\mathrm{CC}$ rate between males and females in the total population $(p=0.87)$. Males compressed deeper than females $(23.95(9.73)$ vs. 20.61(7.66) $\mathrm{mm}, \quad p<0.05)$ and $C C$ fraction was significantly higher with females $(87.9$ $(85.5,95.6)$ vs. $94.4(88.7,96.8) \%, p<0.05)$.

There was no statistical difference between $C C$ rate $(p=0.89)$ and fraction $(p=0.16)$ in males vs. females in the audio-visual CPR rate feedback group, but the difference in CC depth was significant $(26.77(8.44)$ vs. $22.75(7.11) \mathrm{mm}, \mathrm{p}<0.05)$.

There was no statistical difference in males vs. females for CC rate $(p=0.44)$ and depth $(p=0.27)$ in the group without CPR rate feedback, but CC fraction was significantly higher with females $(86.7(83.8,94.4)$ vs. $92.7(88.7,96.0) \%, p<0.05)$.

\section{Conclusions:}

$\mathrm{CC}$ rate, depth and fraction improve with the addition of audio-visual CPR rate feedback. Males performed CC at higher depths than females. CC fraction was significantly higher than the $60 \%$ recommended by the ERC guidelines. 

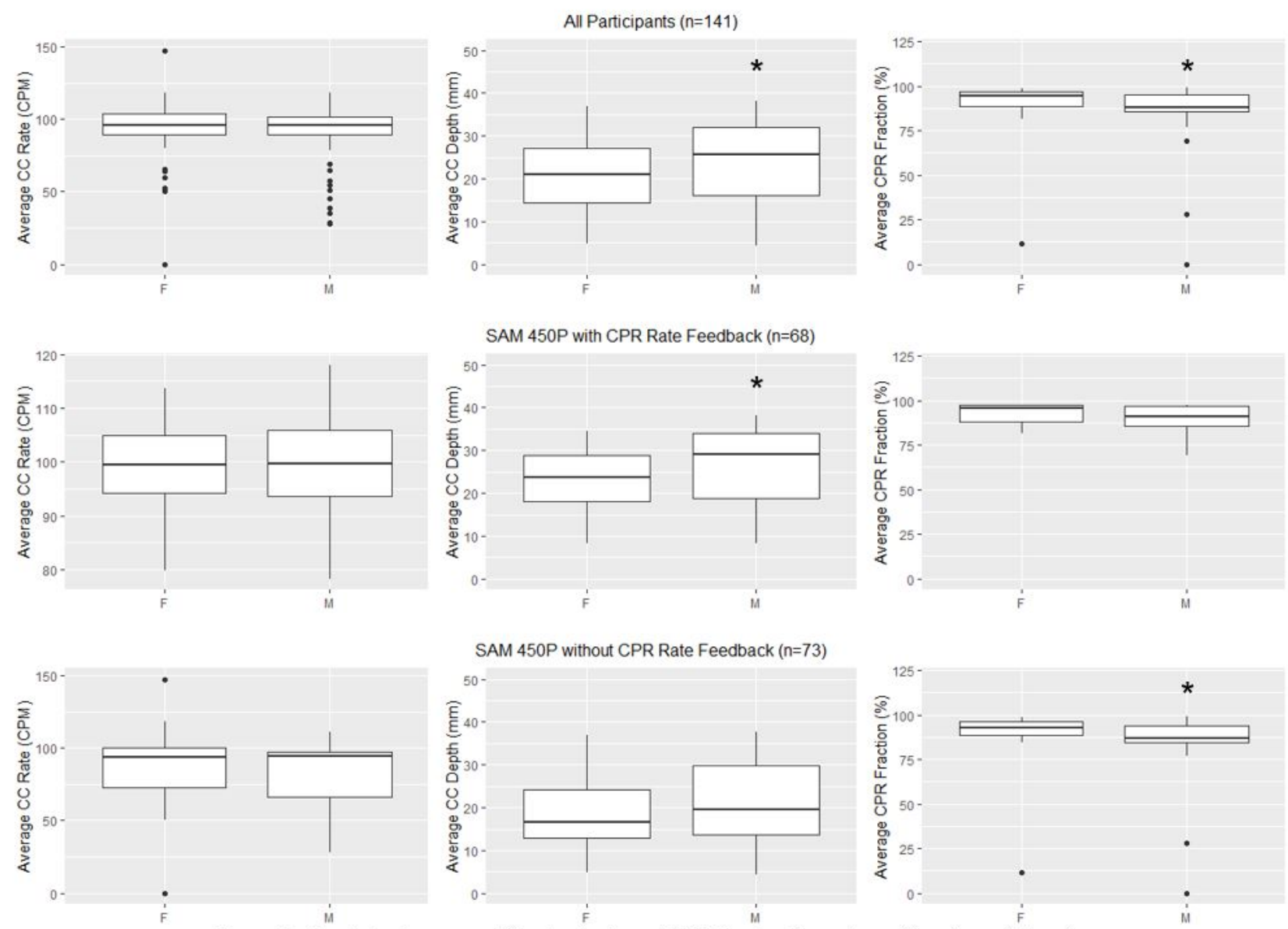

Figure 1: Boxplots of average $\mathrm{CC}$ rate, depth and $\mathrm{CPR}$ fraction for male and female participants. ${ }^{*}$ Denotes statistical significance $(p<0.05)$ 